\title{
ANNOUNCEMENTS
}

\section{Special Issue of Physiological Psychology The Role of the Hippocampus in Learning and Memory}

The June 1980 issue of Physiological Psychology will be a special issue containing the papers from a symposium on The Role of the Hippocampus in Learning and Memory. Contributors to the issue include: T. W. Berger, P. L. Ellen, R. Hirsh, R. L. Isaacson, L. W. Jarrard, R. P. Kesner, J. W. Moore, L. W. Nadel, J. O'Keefe, D. Olton, W. R. Salafia, P. R. Solomon, R. F. Thompson, and G. Winocur. The conference was held at Williamstown, Massachusetts, on June 25, 26, and 27, 1979.

\section{0th International Congress of Electroencephalography and Clinical Neurophysiology Kyoto, Japan \\ September 13-18, 1981}

The 10th International Congress of Electroencephalography and Clinical Neurophysiology will be held in Kyoto, Japan, under the auspices of the International Federation of Societies for Electroencephalography and Clinical Neurophysiology, September 13-18, 1981. The Congress will immediately precede the Epilepsy International Congress, 1981, and the 12 th World Congress of Neurology at the same location. 